\title{
The influence of managerial satisfaction on corporate environmental performance and reputation
}

\author{
Tiberio Daddi ${ }^{1}$ (D) | Fabio Iraldo ${ }^{1}$ | Francesco Testa $^{1}$ (D) | Maria Rosa De Giacomo ${ }^{2}$
}

\author{
${ }^{1}$ Sant'Anna School of Advanced Studies, \\ Institute of Management, Pisa, Italy \\ ${ }^{2}$ University College London, Institute for \\ Sustainable Resources, London, UK \\ Correspondence \\ Tiberio Daddi, Sant'Anna School of Advanced \\ Studies e Institute of Management, Piazza \\ Martiri della Libertà 33, 56127 Pisa, Italy. \\ Email: tiberio.daddi@sssup.it
}

\begin{abstract}
Organizational studies have widely debated the relationship between job satisfaction and job performance. Some papers have dealt with managerial satisfaction and businesses' performance adopting agency theory to interpret the results. However, no studies have yet considered the relationship between the satisfaction levels of an environmental manager and corporate environmental performance. This paper thus analyses the role played by the environmental manager's satisfaction in enhancing corporate environmental performance and reputation. The paper uses data from a survey of 412 Eco Management and Audit Scheme registered organizations. The results show a positive relationship between managerial satisfaction and environmental performance, whereas no such positive relationship was found when considering eco-innovation performance. In addition, the environmental manager's satisfaction has a positive and indirect influence on the corporate environmental reputation. These results contribute to the literature on agency theory and aim to extend the debate between job satisfaction and job performance to the sustainable business field.
\end{abstract}

\section{KEYWORDS}

eco-innovation, Environmental Management Systems, environmental performance, managerial satisfaction, structural equation model

\section{I INTRODUCTION}

The relationship between satisfaction and business performance has been widely debated in management and organizational studies. Theories on organizational psychology and business management have explored the motivational factors that determine higher satisfaction and performance (Chung, 1968), and studies on team motivation have affirmed that one of the drivers of effective outcomes is satisfaction (Hackman \& Walton, 1986). One of theories applied to interpret this relationship is the upper-echelons theory. It supports the interplay among demographic features, cognitive values, and strategic preferences of a human (Hambrick \& Mason, 1984; Wiersema \& Bantel, 1992). These theorists also suggest that the organizational outcomes are manifestations of the values and preferences of their top management teams (Finkelstein \& Hambrick, 1996; Hambrick, Cho, \& Chen, 1996). At the business level, papers have focused on the relationship between job satisfaction and the performance of employees
(Fisher, 1980; laffaldano \& Muchinsky, 1985; Judge, Thoresen, Bono \& Patton, 2001; Schwab \& Cummings, 1970; Vroom, 1964). Many of these studies stated a positive interplay between job satisfaction and job performance (Bakker \& Oerlemans, 2011). For example, Yee, Yeung, and Edwin Cheng (2008) observed that a higher level of job satisfaction of an employee is positively linked with higher quality and profitability in the service industry. Similarly, Delmas and Pekovic (2013) found that job satisfaction and employee motivation positively affected their labour productivity. In business studies, management scholars have read the findings in this field mainly through the lens of agency theory. According to this theory, an agent (e.g. the employee) is hired by one (or more) subject (s) called principal (s) (e.g. the employer) under a contract and is compensated by the principal to achieve their desired outcomes (Miles, 2012). This principal-agent relationship also offers interesting indications in interpreting the results of this paper.

In a marginal way, some studies has focused on a specific category of employees, that is, on the relationship between managerial 
satisfaction and business performance. For instance, by studying managers of an IT company, Ziegler, Hagen, and Diehl (2012) found that the job satisfaction can help to identify the effects on performance arising from the job. Similarly, Netemeyer, Maxham, and Lichtenstein (2010) looked at managers' performance and satisfaction from a psychological, rather than a managerial, perspective. However, it is believed that there are no studies which have investigated the relationship between managerial satisfaction and corporate environmental performance.

The aim of this paper is thus, first, to contribute to the literature on managerial satisfaction and performance, and second, to extend the discussion in this field to include the environmental management perspective, i.e. considering the environmental manager's job satisfaction and the environmental performance of the organization. To achieve this objective, a survey of a sample of Eco Management and Audit Scheme (EMAS) registered organizations is used. The remainder of this paper is structured as follows: section 2 describes the theoretical framework and hypotheses developed, section 3 outlines the methodology and the sample used, section 4 presents and discusses the results, and Section 5 reports the conclusions drawn.

\section{I THEORETICAL FRAMEWORK AND DEVELOPMENT OF HYPOTHESES}

\section{1 | Managerial satisfaction in companies with a certified Environmental Management System}

To test the hypotheses the results of an EMAS Evaluation Study related to a sample of EMAS registered organisations was used. The consequences of EMAS registrations, and more generally of Environmental Management Systems (EMSs) such as ISO14001 on corporate management, have been extensively studied. The EMAS is considered one of the main certifiable EU tools (Merli, Preziosi, \& Ippolito, 2016; Testa et al., 2014), and in the past many scholars have studied its effects on corporate environmental management. Some studies have dealt with the effects of EMAS and EMSs on environmental performance (Ammenberg, Hjelm, \& Quotes, 2002; Comoglio \& Botta, 2012; Daddi, Magistrelli, Frey, \& Iraldo, 2011; Melnyk, Sroufe, \& Calantone, 2003), while others have focused mainly on the drivers underlying their adoption (Daddi, Testa, Frey, \& Iraldo, 2016; HerasSaizarbitoria, Arana, \& Boiral, 2016; Morrow \& Rondinelli, 2002) or on the spread of EMSs among small and medium-sized enterprises (SMEs) (Ammenberg \& Hjelm, 2003; Daddi \& Iraldo, 2016; Zorpas, 2010). Recently, some papers have studied the stagnation or decrease of EMAS registrations, identifying several reasons such as the current economic crisis (Daddi, De Giacomo, Frey, \& Iraldo, 2017; HerasSaizarbitoria, Boiral, \& Arana, 2016; Merli \& Preziosi, 2018). Despite the high number of papers on EMAS and EMSs, no publications have dealt with the level of satisfaction of environmental managers from environmental certified companies.

The first hypothesis $(\mathrm{H} 1)$ is thus that external auditors are one of the main actors that could influence the environmental manager's satisfaction, which in the case of EMAS registration are called environmental verifiers. The environmental audit is the last step in the annual plan-do-check-act cycle applied to enterprises having a certified environmental management system. The auditor (or team of auditors) assesses the work carried out by the environmental manager and their audit report should help to increase the environmental management at firm level (Heras-Saizarbitoria, Dogui, \& Boiral, 2013; Testa, Iraldo, \& Daddi, 2018), and also contribute to the overall satisfaction of environmental managers. The literature on the relationship between auditors/verifiers and certified companies is not wide-ranging and mainly focuses on specific topics such as auditor independence (Dogui, Boiral, \& Heras-Saizarbitoria, 2014) or the auditor's interpretation of the standard's requirements (Ammenberg, Wik, \& Hjelm, 2001). The first hypothesis represents a contribution to the existing theoretical framework by considering the relationship between the environmental verifier and the manager's satisfaction.

Hypothesis 1. The higher the knowledge of environmental verifiers, the higher the satisfaction of the environmental manager will be.

In addition, this first hypothesis is also coherent with agency theory. According to the principal-agent model, job performance should have a positive effect on job satisfaction (Brown \& Peterson, 1994). Verifiers are particularly linked with performance; their role is to evaluate the firm environmental performance to release or confirm the environmental certification.

In addition, the relationship presumed in the first hypothesis could be positive in the case of a full internalization of the Environmental Management System, that is, companies applying the standard in an effective way avoiding symbolic behaviour (Testa, Iraldo, \& Daddi, 2018).

\section{2 | Managerial satisfaction and corporate environmental performance: eco-innovation, environmental performance and environmental reputation}

Managerial satisfaction can be defined as "a key measure of individual entrepreneurial success" (Carree \& Verheul, 2012, pp. 372). The concept of managerial satisfaction includes different levels of satisfaction that can be either extrinsic or intrinsic. Extrinsic level deals with material characteristics of the work (including, for example, wage, job security or career opportunity), while the intrinsic level includes qualitative features of the job (such as the kind of the work and the relationships). Managerial satisfaction may also be influenced by values and personality features, but also by a scarce aversion to risk (Bradley \& Roberts, 2004; Cooper, Woo, \& Dunkelberg, 1988). Briefly, if people are more motivated or find satisfaction in doing their work, they will achieve a higher performance (Strauss, 1968; Vroom, 1964). The connection between extrinsic satisfaction is widely debated in the agency theory literature. In an agency theory context, incentives, bonuses, and promotion designed to encourage extrinsic motivation are held to be indispensable (Osterloh, Frost, \& Frey, 2002). In addition, agency theory describes a possible problem that can occur in the agency relationship and affect corporate performance. It is called the "agency problem" and it deals with the potential for managers to misbehave if the interests of the company owners and the agent managers 
diverge (Dalton, Hitt, Certo, \& Dalton, 2007). If the principal and the agent both seek to maximize their own self-interests in this relationship, then the agent may not always act in the best interests of the principal (Jensen \& Meckling, 1976). To minimize this problem which can negatively influence managerial satisfaction and corporate performance (including environmental performance), there are methods such as board independence (the main role of the board is to monitor the behaviour of managers), agent equity ownership (managers share ownership of the company and thus help to advance shareholders' interests) (Dalton, Hitt, Certo, \& Dalton, 2007).

Whether managerial satisfaction can also affect environmental management issues, including the eco-innovation implementation, is not clear. Some of the literature has explored the interplay between the Environmental Management System and the green innovation of companies, highlighting positive and negative relations. Rennings, Ziegler, Ankele, and Hoffmann (2006) explored the effect of EMAS on economic performance and on technical green innovation in EMAS sites in Germany. Their survey was based on 1277 companies and reported a totally positive effect of the EMS on process innovations, including an environmental dimension. Grolleau, Mzoughi, and Pekovic (2015) found that ISO 14001 certification promotes innovation, and their findings highlighted the EMS's ability to stimulate environmental investment. Lim and Prakash (2014) reported a positive link between the number of ISO 14001 certificates and environmental patents at national level. In a survey with German organizations, Frondel, Horbach, and Rennings (2008) found that innovation at environmental level was not linked with the adoption of an Environmental Management System.

As previously mentioned, most scientific studies have addressed the question of environmental management and innovation in general by covering EMAS as well as ISO 14001. Other studies have analysed the drivers of eco-innovation, identifying market pull, environmental regulation and cost savings as the main determinants (Cleff \& Rennings, 1999; Triguero, Moreno-Mondéjar, \& Davia, 2013).

Although these studies investigated whether an EMS stimulated the adoption of eco-innovation, the existing literature has not paid attention to specific drivers of eco-innovation in certified organizations such as managerial satisfaction. The second hypothesis is thus:

Hypothesis 2. The higher the level of satisfaction of the environmental manager, the higher the level of environmental eco-innovation adopted at the firm level.

In addition to the relationship between managerial satisfaction and eco-innovation adoption, this paper considers if the implementation of eco-innovation determines an increase in the environmental reputation of a company. In the literature, the effects of eco-innovation have been investigated mainly in relation to economic (Aguilera-Caracuel \& Ortiz-de-Mandojana, 2013; Daddi, Tessitore, \& Frey, 2012; Tessitore, Daddi, \& Iraldo, 2013; Zahra \& Das, 1993) or environmental performance (Carrión-Flores \& Innes, 2010; Chiou, Chan, Lettice, \& Chung, 2011). However, the relationship between eco-innovation and reputation at environmental level has not been investigated.

Fombrun and Shanley (1990) highlighted how firms compete to obtain a higher reputational status, and they consider reputation in terms of results related to a competitive process in which companies distinguish their distinctive features with the aim to increase their social position (Fombrun \& Shanley, 1990; Spence, 1974). In the field of environmental management, environmental reputation has been identified as being positively related to the environmental reporting activities of organizations (Dixon, Mousa, \& Woodhead, 2005) and as a leverage to obtain specific benefits. For example, some studies have shown how environmentally certified firms are considered to have a higher reputation by public authorities which thus enables them to obtain regulatory (Daddi, Testa, Iraldo, \& Frey, 2014; Testa, Heras-Saizarbitoria, Daddi, Boiral, \& Iraldo, 2016; Wätzold, Bültmann, Eames, Lulofs, \& Schucht, 2001) and monetary incentives (Boiral, Guillaumie, Heras-Saizarbitoria, \& Tayo Tene, 2018). Although some papers have examined the consequences of environmental reputation, few empirical investigations have sought to understand the factors that influence environmental reputation. The third hypothesis is thus:

Hypothesis 3. Eco-innovation performance is positively related with corporate environmental reputation.

Since the publication of the first version of the EMAS Regulation in 1993, one of the scheme's main aims has been to stimulate environmental performance within registered organizations: the principle of continuous performance improvement is key to EMAS's efforts in this regard (Daddi, Magistrelli, Frey, \& Iraldo, 2011). The increase in environmental performance is a key objective of EMAS and more generally of EMSs; several authors have confirmed this positive relationship at the organizational (Daddi, Magistrelli, Frey, \& Iraldo, 2011; Nishitani, Kanekob, Fujiic, \& Komatsu, 2012) and national levels (Daddi, Frey, De Giacomo, Testa, \& Iraldo, 2015; Lim \& Prakash, 2014; Potoski \& Prakash, 2013) while other authors have highlighted controversial results (Ammenberg, 2007; Zobel, 2016). Similarly to the previous hypothesis in regard to eco-innovation, in this case also the objective is to verify whether the positive influence of managerial satisfaction on environmental performance could affect an organization's environmental reputation, thus:

Hypothesis 4 . The higher the environmental manager's
satisfaction, the higher the level of environmental perfor-
mance achieved by the organization.

Hypothesis 5. Environmental performance is positively related with the corporate environmental reputation.

Hypotheses 2-5 have the objective to investigate the influence of the environmental manager's satisfaction in relation to different characteristics of the certified organization such as eco-innovation, environmental performance and, using these variables as mediations, on the corporate environmental reputation. In the last hypothesis $(\mathrm{H} 6)$, similarly to $\mathrm{H} 1$, the aim is to explore the drivers of managerial satisfaction and whether the environmental reputation can be considered not only a cause of managerial satisfaction $(\mathrm{H} 2-\mathrm{H} 5)$ but also as a determinant. The relationship between job performance and job satisfaction has been discussed in previous management and organizational psychology studies. This research has produced contradictory results; some of them observed a weak relationship (Brown \& Peterson, 1994; laffaldano \& Muchinsky, 1985) while other studies highlighted a positive effect (Christen, Iyer, \& Soberman, 2006). This 
last hypothesis is consistent with literature aiming to extend the discussion to the field of the relationship between environmental performance and environmental manager satisfaction:

Hypothesis 6. Corporate environmental reputation is positively related to environmental manager satisfaction.

To facilitate the understanding of the connections between the different hypotheses, Figure 1 summarizes the theoretical scheme and the six hypotheses.

\section{I RESEARCH METHODS}

\section{1 | Data source and sample}

EMAS is re-evaluated at regular intervals. Based on these evaluations, the European Commission and EU Member States decide whether a revision of the scheme is necessary. The source of data used in this paper is the EMAS Evaluation Study which is the most recent evaluation of EMAS carried out by the EU Commission. The results were summarized in a report completed in 2015 (Weiss et al., 2015) which was published in June 2017 by the EU Commission within the framework of the EMAS and Ecolabel Fitness Check initiative (http:// ec.europa.eu/environment/emas/emas_publications/policy/fitness_ check_en.htm). The authors of this paper were part of the research team charged with conducting the study.

During the study, an extensive online survey involved EMAS-registered organizations in order to explore many EMAS features. A questionnaire was drafted, translated into Italian, German, Spanish and English. It was sent for feedback to the Commission as well as to over 50 EMAS stakeholders and experts before being completed in its final form. Although nearly all the questions were multiple choice, comment boxes were also included to enable organizations to add information or details. Most questions used the 1-5 Likert scale, designed to reduce ambiguity in answers by providing respondents with a range of values to choose from. The project team obtained email contact details for all EMAS-registered organizations from the EU EMAS Register and several EMAS Competent Bodies. All EMAS-registered organizations received emails from the project team containing links to the online survey, a PDF download and an explanation of the reasons behind the survey. EMAS Competent Bodies were also informed of the survey's distribution and asked to encourage organizations in their countries to take part. The survey was available from 5 to 29 June 2014. During this time, a reminder was sent to the organizations. By request, several participants were granted extensions until 4 July 2014 , when the data collection phase officially closed.

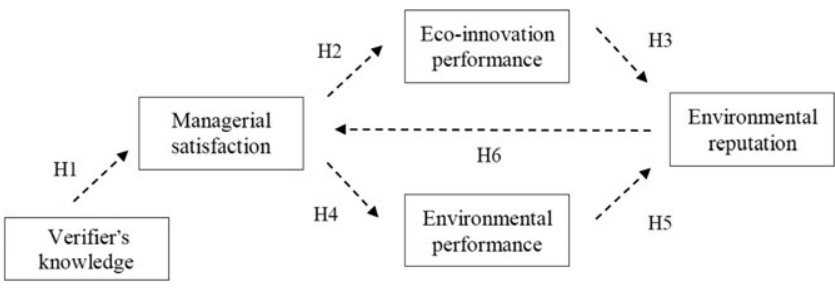

FIGURE 1 The six hypotheses
A total of 467 EMAS-registered organizations filled out the online questionnaire. In this paper 412 questionnaires were identified as usable to test the model, with a representation of $10.23 \%$ of the total EMAS population over that period. This response rate is relevant in terms of representation and it is one of the highest response rates ever achieved by a survey focused on EMAS organizations.

The respondents were located in $21 \mathrm{EU}$ member states; the highest response rates were from Italy, Germany, Spain and Austria. The sample had different levels of turnover and had adopted EMAS at different times (Table 1).

The sample is well represented in terms of turnover and length of EMAS registration. About $40 \%$ of the total sample has a turnover $>50$ million euros; with regard to the date of the first EMAS registration, the sample is well balanced according to the five indicated categories.

Since self-reported data was used and all variables are measured using the same source, several procedural remedies were needed to minimize and control for the common method variance. Following Podsakoff, MacKenzie, Lee, and Podsakoff (2003), long, complex questions were avoided, and a bipolar numerical scale with values and verbal labels for the midpoints of scales was used. Finally, respondent anonymity was guaranteed.

Harman's single-factor test to reveal any bias was used. Although the reliability of this test is controversial (Podsakoff, MacKenzie, Lee, \& Podsakoff, 2003), Fuller, Simmering, Atinc, Atinc, and Babin (2016) recently showed that this criticism is partially unfounded. The results of the test highlighted the absence of a single factor or one general factor accounting for the majority of covariance among the measures.

\section{2 | Development of variables and model specifications}

On the basis of the survey, data was used to build the variables needed to test the model. One of the key variables was managerial satisfaction, which is a broad concept that can be analysed from several points of view. To decide how to measure this variable, it was taken into account that the sample was related to a survey that involved environmental managers from EMAS-registered companies. It was thus hypothesized that the satisfaction of the environmental managers could be estimated by starting with their satisfaction with the work carried out by the environmental verifier, which represents the final step in the periodical certification process. The environmental verifier acts as a third party audit and verifies the effectiveness of the EMS, and its capacity to obtain continuous improvements. In other

TABLE 1 Sample features

\begin{tabular}{|lcll|}
\hline Turnover (euros) & $\begin{array}{l}\text { Response } \\
\text { rate (\%) }\end{array}$ & $\begin{array}{l}\text { Length of EMAS } \\
\text { registration }\end{array}$ & $\begin{array}{c}\text { Response } \\
\text { rate (\%) }\end{array}$ \\
\hline$<1000000$ & 7.7 & $\begin{array}{c}\text { Adoption in 2002 or } \\
\text { before }\end{array}$ & 26.3 \\
\hline 1000 001-2000 000 & 6.3 & $\begin{array}{c}\text { January 2003- } \\
\text { December 2005 }\end{array}$ & 17.3 \\
\hline 2000 001-10 000 000 & 24.4 & $\begin{array}{c}\text { January 2006- } \\
\text { December 2008 }\end{array}$ & 21.9 \\
\hline $10000001-50000000$ & 21.1 & $\begin{array}{c}\text { January 2009- } \\
\text { December 2011 }\end{array}$ & 19.4 \\
\hline 50000000 & 40.6 & After January 2012 & 15.2 \\
\hline
\end{tabular}


words, the verifier assesses the work carried out by the environmental manager, and each environmental manager also has high expectations regarding the contribution provided by the environmental verifier with the external audit (Bernardo, Casadesus, Karapetrovic, \& Heras, 2011). Table 2 reports the items of the questionnaire used to develop the variable of managerial satisfaction. The environmental managers replied indicating their level of satisfaction using a scale from 1 to 3 .

The same approach that was used for the variable of managerial satisfaction was also used for the other variables, and it was decided to aggregate different questionnaire items to develop the variables. The knowledge of the verifiers was measured taking into account the main component of knowledge identified by previous studies (see, for instance, Ammenberg, Wik, \& Hjelm, 2001; Dogui, Boiral, \& HerasSaizarbitoria, 2014). Managers were asked the question "How would you rate your environmental verifier's knowledge of the following aspects?" and gave a rating of the knowledge of the particular environmental verifier (from 1 to 5 , where 5 indicates very high knowledge). The aspects linked to the knowledge of the environmental verifiers (considering the requirements included in the standard ISO19011) after the question was asked were: environmental protection; technical issues; organizational issues; knowledge of applicable environmental legislation; knowledge of EMAS requirements; sector-specific knowledge; independence; reliability; and scope of examination.

Environmental performance was measured in a multitude of ways using self-reported information. According to a consolidated approach used in previous studies (see, for instance, Arimura, Hibiki, \& Katayama, 2008; Lanoie, Laurent-Lucchetti, Johnstone, \& Ambec, 2011; Testa et al., 2014), firms' environmental performance was measured using the survey question: "With reference to the production unit, how has the environmental performance of your organization changed over the last few years in the following areas?". A five-point Likert-scale (where the value 1 indicates "not improved" and 5 indicates "strongly improved") was then used considering the following environmental aspects: efficiency in the use of materials, water consumption; waste production; quality/quantity of wastewater effluents; and quality/quantity of air emissions.

The fourth variable to estimate was eco-innovation performance. According to the vision of eco-innovation described by Rennings, Ziegler, Ankele, and Hoffmann (2006), who distinguish between process and product innovation, eco-innovation was measured by asking managers to indicate their "level of agreement on the effect of EMAS on process and product innovation." Respondents replied by assigning a score from 1 to 5 (1: strongly disagree; 5 : strongly agree) to a set of five items indicating process innovation: EMAS stimulates the adoption of green technology or BATs (Best Available Techniques); EMAS

TABLE 2 Items of the questionnaire used to estimate the managerial satisfaction of the environmental managers interviewed

$\begin{array}{ll}\text { Variable } & \text { Item used to estimate the variable } \\ \text { Managerial } & \text { a) Are you satisfied with the work carried out by your } \\ \text { satisfaction } & \text { environmental verifier? } \\ \text { b) Are you satisfied with the expertise of your } \\ \text { environmental verifier with regard to auditing? } \\ \text { c) Does your environmental verifier contribute to the } \\ \text { improvement in environmental management in your } \\ \text { organization? }\end{array}$

stimulates the level of investment in innovative environmental technologies; EMAS improves the level of investment by identifying more sustainable production processes; EMAS stimulates initiatives between registered companies and neighbouring companies (e.g. through product exchanges and energy exchanges); EMAS stimulates innovations linked with specific tasks or processes such as equipment maintenance, handling of chemicals, storage, dosing and dispensing. Similarly, in the questionnaire, three items were listed to estimate the performance in product innovation: EMAS influences the design and development of the products; EMAS contributes to assessing the environmental effects of new products or of substantial product changes; EMAS contributes to the adoption of innovative tools for assessing and enhancing the sustainability of products (e.g. Life-Cycle Analysis, Product/Organization Environmental Footprint, Ecolabel).

Finally, to test the model, the last variable developed considered environmental reputation. Increasing corporate reputation is one of the main drivers that encourages an organization to adopt environmental initiatives (Testa, Boiral, \& Iraldo, 2018). To measure the impact of managerial satisfaction on a firm's reputation, the answers to the following question were used: "What kind of competitive advantage does your organization experience by participating in EMAS?" Managers replied indicating their level of agreement using a scale from 1 to 5 , with the following statements aggregated to estimate the variable: (i) improved corporate image in the eyes of local and national domestic customers and suppliers; (ii) improved corporate image towards international customers and suppliers; and (iii) increase in consumers/customers' trust in the organization.

Table 3 shows that for all variables reliability is high since the Cronbach alpha coefficient is consistently $>0.7$, as recommended when a combination of variables contributes to the development of a single construct (Cortina, 1993).

\section{4 | RESULTS}

To test the hypotheses structural equation modelling (SEM) was performed.

First, the validity of the proposed measurement model was checked by performing a confirmatory factor analysis (Anderson \& Gerbing, 1988). The results indicated that the data fitness was acceptable: the comparative fit index (CFI) and the Tucker Lewis index (TLI) were close to 0.90 (0.901 and 0.883 , respectively) and the rootmean-square error of approximation (RMSEA) was 0.077, lower than the recommended threshold of 0.08 (lacobucci, 2010).

Second, convergent validity, discriminant validity and internal consistency were checked to validate the adequacy of the measurement

TABLE 3 Cronbach alpha coefficient of the variables

\begin{tabular}{lll} 
Variable & Items & Alpha coefficient \\
\hline Managerial satisfaction & 3 & 0.726 \\
\hline Verifiers knowledge & 9 & 0.926 \\
\hline Eco-innovation performance & 5 & 0.821 \\
\hline Environmental performance & 8 & 0.892 \\
Environmental reputation & 3 & 0.823
\end{tabular}


model. All standardized loadings were found to be significantly related to their constructs $(p<0.001)$ and $>0.5$. The value of Average Variance Extracted (AVE) ranged from 0.48-0.61, which is (except for the latent variable environmental performance) greater than the suggested threshold of 0.50 (Hair, Black, Babin, Anderson, \& Tatham, 1998).

Discriminant validity is the degree to which items do not correlate with scores from other items that are not designed to measure the same construct. As was highlighted in the paper, and according to Hair, Black, Babin, Anderson, and Tatham (1998), discriminant validity was positively verified by the value of AVE for each construct being greater than the squared correlation among the latent variables.

Finally, the SEM revealed satisfactory goodness of fit indices, $\chi^{2}=$ 4.99 and is not significant; $\mathrm{CFI}=0.992 ; \mathrm{TLI}=0.973$; and RMSEA = 0.040 . Table 4 shows the results of the structural equation model.

The model highlights four significant and positive relationships among the variables, whereas two relationships were not significant. The first hypothesis was confirmed. Verifier knowledge positively influences managerial satisfaction. Following the theoretical model, the SEM confirms that the satisfaction of the environmental manager has a positive influence on environmental performance $(\mathrm{H} 4)$, but does not contribute to the adoption of eco-innovation by the organization $(\mathrm{H} 2)$. In addition, regarding the environmental reputation as the dependent variable, verifier knowledge is positively linked with eco-innovation performance $(\mathrm{H} 3)$, while the relationship with environmental performance was not confirmed (H5). Finally, the model considered the environmental reputation as an independent variable in order to verify its influence on managerial satisfaction $(\mathrm{H} 6)$. In this case, the relationship is significant and positive, which confirms that high environmental reputation of an organization contributes to increasing levels of satisfaction for the environmental manager, confirming previous literature findings about job performance and job satisfaction (Christen, lyer, \& Soberman, 2006), including those contributions in the field of agency theory that (as described earlier in the literature review) indicate a positive relationship between job performance and job satisfaction (Brown \& Peterson, 1994). Figure 2 summarizes the results.

\section{5 | DISCUSSION}

The results obtained with the model provide interesting information about the relationships between the investigated variables, leading to a greater understanding about how manager satisfaction originates

TABLE 4 Structural equation model results

\begin{tabular}{lllll} 
& \multicolumn{4}{l}{ Number of observations $=412$} \\
\cline { 2 - 5 } Structural equation model & & OIM \\
Estimation model = mlmv & Coefficient & Std. error & $z$ & P > z \\
verf_know - > env_satisf & 0.56983 & 0.04161 & 13.7 & 0.000 \\
\hline env_satisf - > eco-innov_perf & 0.47128 & 0.05857 & 0.80 & 0.421 \\
\hline eco-innov_perf - > envi_rep & 0.45445 & 0.04676 & 1.44 & 0.000 \\
\hline env_satisf - > envi_perf & 0.12635 & 0.05691 & 2.22 & 0.026 \\
\hline env_perf - > envi_rep & 0.07497 & 0.05217 & 1.44 & 0.151 \\
\hline envi_rep - > env_satisf & 0.10012 & 0.04877 & 2.05 & 0.040 \\
\hline
\end{tabular}

Abbreviations: eco-innov_perf, eco-innovation performance; envi_perf, environmental performance; envi_rep, environmental reputation; env_satisf, environmental satisfaction; verf_know, verifiers knowledge.

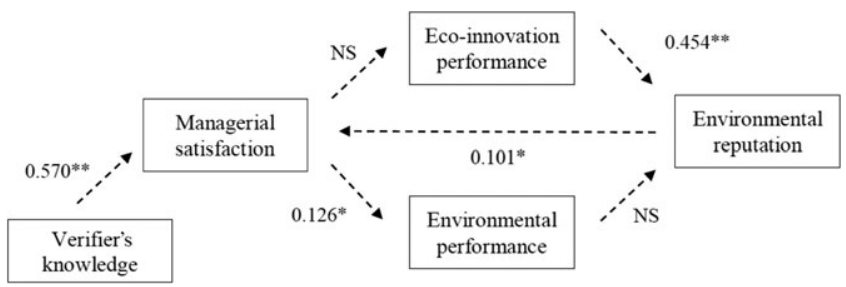

FIGURE 2 Summary of results. *, significant at 10\%; **, significant at $5 \%$; NS, not significant

from various drivers, and is itself a driver for performance, and is also influenced by reputation.

First, a positive statistical relationship was found between the perception of managers of the skills and knowledge shown by the external verifiers and the level of satisfaction of these managers. Generally speaking, and according to authors' experiences, environmental managers are interested in gaining added value from their relationship with the external verifier because of the verifier's capacity to carry out the assessment in a thorough and independent way and, therefore, in reliably guaranteeing their certification. In most cases, what the environmental managers expect from the verifier is the ability to spot weaknesses and potential improvements in the environmental management system, which is fundamental for the effectiveness of the EMS. This added value derives from the knowledge provided in the feedback that the verifiers give to the manager. Thus, the manager will take on board the indications arising, for example, from the verifier's recommendations or the conclusions of the report. These indications can then be turned into improvements in the EMS.

Second, when checking for a direct influence of the managers' satisfaction on environmental performance, the outcome of the model shows that the higher their level of satisfaction, the better the environmental performance of their company. In fact, a manager may become more committed and make greater efforts in doing their job in terms of leadership and involvement when driven by strong satisfaction. In addition, a manager who is very satisfied is normally also eager and able to motivate people around them, and to provide a good role model. This can produce a multiplier effect, creating a positive working environment and encouraging others to collaborate in the same direction.

Third, satisfaction can also be seen as self-fulfilment stemming from the ability to achieve results. This produces a virtuous cycle, in which the satisfaction comes from the demonstration that even ambitious objectives in environmental performance can actually be achieved, which creates trust in being able to continue along the same route.

The model also aimed to test the specific relationship between satisfaction and eco-innovation performance. In this case, the outcome is not conclusive: the statistical relationship between the two variables appears to be non-significant. This can be explained by the organizational approach companies adopt for environmental management. Whereas environmental managers are autonomous in taking decisions to prompt environmental improvement in the organizational and operational dimensions (such as working routines and procedures, operational modalities, changes in the layout, ordinary maintenance and the training of employees), when it comes to innovation they need to plan investments, which involves a higher level of decision-taking. For example, when the adoption of green technologies is envisaged, 
the decision to invest cannot normally be taken by one manager (e.g. the environmental manager or the EMS responsible), but needs wider consensus and, since it requires more economic resources, has to be discussed and approved of at higher organizational levels. This means that the level of satisfaction of the environmental manager is less effective in influencing the outcome of the process. It might well be that a very satisfied environmental manager cannot take the decision to invest in a greener innovation on their own, but that good performance depends on the co-decisions of several other types of managers in the organization, with a very high level of uncertainty. Therefore, the study cannot draw conclusions regarding the relationship between the environmental manager's satisfaction and the performance in terms of eco-innovation.

Regarding the ability of performance to affect a company's reputation, the study only confirms a statistically significant relationship with eco-innovation. Once again, this is linked with the particular context in which environmental management is carried out at the company level. When dealing with environment-related issues, company reputation is essentially built on the ability to engage stakeholders and gain their consensus. From this perspective, the difference between environmental and eco-innovation performance in influencing reputation can be interpreted. As is well known, environmental performance is very difficult to communicate: it involves technical competence; it is not always measurable, or tangible by stakeholders, who may not be able to appreciate it (as has been seen before with respect to employees); and it is affected by uncertainties or debated by the media (e.g. the greenhouse effect). Conversely, eco-innovation performance is easier to explain and communicate to stakeholders, since it is more easily perceived. Recycled products, lighter packaging, green technologies, product durability, and water savings are all examples of innovations that can be understood and/or can be effectively described and communicated to a wide range of stakeholders (consumers, Non Governative Organisations (NGOs), researchers, etc.). This is why eco-innovation performance has a significant effect on reputation, whereas environmental performance turns out to be a non-significant variable in the model.

Finally, the current study investigated the reverse relationship between reputation and manager satisfaction. The aim was to understand whether a virtuous cycle can be created between these two variables. The idea is that satisfaction can be fed by an improvement in the company's environmental reputation which, if this is true, can be deemed to activate beneficial spillovers on the people involved in environmental management. The model confirms this spillover: when a company improves its reputation, this is most likely seen as a result of the effort made by the managers which, therefore, increases their level of satisfaction. This result confirms previous studies on agency theory about the positive relationship between job performance and job satisfaction (Christen, Iyer, \& Soberman, 2006). Indeed, in the model, environmental reputation is not only a type of performance, but is also influenced by eco-innovation performance.

\section{6 | CONCLUSIONS}

This study contributes to the debate on the relationship between managerial satisfaction and performance with a focus on the agency theory context. Since most papers have mainly focused on employee satisfaction and performance, the focus on the managerial perspective has remained relatively unexplored. In addition, considering the specific theme of the study, that is, the relationship between environmental managers' satisfaction and environmental performance, this study has several managerial and policy implications.

A clear message is highlighted for top level managers (e.g. CEOs) regarding the environmental manager's satisfaction: environmental performance is positively related to the satisfaction of the environmental manager. Environmental performance is an important objective because, in the case of an increase in resource efficiency, it leads to reduced costs for companies by increasing their competiveness (Porter \& van der Linde, 1995), as well as the continuous improvement principle set by environmental certification. In other words, top level managers should consider the satisfaction of environmental managers as a driver of success for the environmental management of the company.

Another managerial implication regards the selection criteria of the environmental verifier as an environmental certification body. Often, EMAS-registered companies, especially SMEs, select their own verifier by comparing different offers and selecting one according to the finances they have available. This approach does not guarantee the most skilled verifier, i.e. someone who could contribute significantly to the environmental management of the company. Considering that a skilled verifier could influence the environmental performance of the organization, a higher cost for a highly skilled verifier could be a good investment with a shorter payback period, compared to a low-skilled verifier.

Policy-makers could take into account these results in their policies for environmental improvement. An environmental policy to reduce the pollution of a firm that aims to motivate and involve environmental managers is probably more effective than a policy that imposes rules with a top-down approach. In fact the latter approach could negatively impact on the satisfaction of managers.

This paper has some limitations. The first limitation is linked with an intrinsic aspect of the online survey. At the beginning of the questionnaire, a disclaimer for the organizations interviewed was included, explaining that the survey aimed to collect the opinions of environmental managers. Despite this disclaimer, the authors cannot be totally sure that all the questionnaires were filled in by environmental managers. At the same time, the focus on environmental managers could be seen as a limitation, since other managers may contribute to corporate environmental performance and reputation. The second limitation is linked to the nature of self-reported data. An important variable such as environmental performance was estimated on the basis of the opinions of the managers. This variable may thus be biased due to the environmental manager wishing to be viewed favourably by others (i.e. social desirability).

Future studies should replicate the approach of this paper, contributing to the field of satisfaction of environmental managers and environmental performance. One possible evolution of this research could deal with a different estimation of the key variable, managerial satisfaction. Scholars could extend the measurement of the satisfaction of environmental managers, starting with the more traditional indicators of employees' satisfaction such as salary, independence, relationships with colleagues, and availability of free time. According to this study's 
results, the drivers of environmental managers' satisfaction are the key determinants in improving environmental performance. Future research could also analyse the agency problem. As described, the problem highlighted by agency theory can be minimized by sharing ownership with the agent (Dalton, Hitt, Certo, \& Dalton, 2007); in this case, the environmental manager. Future studies could sample environmental managers to interview by selecting them in a more specific way, in order to test the possible solutions of the agency problem.

\section{ORCID}

Tiberio Daddi (D) http://orcid.org/0000-0002-9716-3388

Francesco Testa (D) http://orcid.org/0000-0003-4494-8146

\section{REFERENCES}

Aguilera-Caracuel, J., \& Ortiz-de-Mandojana, N. (2013). Green innovation and financial performance: An institutional approach. Organization \& Environment, 26(4), 365-385.

Ammenberg, J. (2007). Environmental management systems and environmental performance. In R. P. Sroufe, \& J. Sarkis (Eds.), Strategic Sustainability: The State of the Art in Corporate Environmental Management Systems (pp. 242-257). Shipley, UK: Greenleaf Publications.

Ammenberg, J., \& Hjelm, O. (2003). Tracing business and environmental effects of environmental management systems-a study of networking small and medium-sized enterprises using a joint environmental management system. Business Strategy and the Environment, 12(3), 163-174.

Ammenberg, J., Hjelm, O., \& Quotes, P. (2002). The connection between environmental management systems and continual environmental performance improvements. Corporate Environmental Strategy, 9(2), 183-192.

Ammenberg, J., Wik, G., \& Hjelm, O. (2001). Auditing external environmental auditors-investigating how ISO 14001 is interpreted and applied in reality. Corporate Social Responsibility and Environmental Management, 8(4), 183-192.

Anderson, J. C., \& Gerbing, D. W. (1988). Structural Equation Modeling in Practice: A Review and Recommended Two-Step Approach. Psychological Bulletin, 103(3), 411-423.

Arimura, T., Hibiki, A., \& Katayama, H. (2008). Is a voluntary approach an effective environmental policy instrument? A case for environmental management systems. Journal of Environmental Economics and Management, 55, 281-295.

Bakker, A. B., \& Oerlemans, W. (2011). Subjective well-being in organizations. In K. S. Cameron, \& G. M. Spreitzer (Eds.), The Oxford handbook of positive organizational scholarship (pp. 178-189). New York, NY: Oxford University Press.

Bernardo, M., Casadesus, M., Karapetrovic, S., \& Heras, I. (2011). Relationships between the integration of audits and management systems: an empirical study. The TQM Journal, 23(6), 659-672.

Boiral, O., Guillaumie, L., Heras-Saizarbitoria, I., \& Tayo Tene, C. V. (2018). Adoption and outcomes of ISO 14001: a systematic review. International Journal of Management Reviews, 20(2), 411-432.

Bradley, D. E., \& Roberts, J. A. (2004). Self-employment and job satisfaction: investigating the role of self-efficacy, depression and seniority. Journal of Small Business, 42(1), 37-58.

Brown, S. P., \& Peterson, R. A. (1994). The Effect of Effort on Sales Performance and Job Satisfaction. Journal of Marketing, 58, 70-80.

Carree, M. A., \& Verheul, I. (2012). What makes entrepreneurs happy? Determinants of satisfaction among founders. Journal of Happiness Studies, 13(2), 371-387.

Carrión-Flores, C. E., \& Innes, R. (2010). Environmental innovation and environmental performance. Journal of Environmental Economics and Management, 59(1), 27-42.
Chiou, T. Y., Chan, H. K., Lettice, F., \& Chung, S. H. (2011). The influence of greening the suppliers and green innovation on environmental performance and competitive advantage in Taiwan. Transportation Research Part E: Logistics and Transportation Review, 47(6), 822-836.

Christen, M., Iyer, G., \& Soberman, D. (2006). Job satisfaction, job performance, and effort: A reexamination using agency theory. Journal of Marketing, 70(1), 137-150.

Chung, K. H. (1968). Developing a comprehensive model of motivation and performance. Academy of Management Journal, 11(1), 63-73.

Cleff, T., \& Rennings, K. (1999). Determinants of environmental product and process innovation. Environmental Policy and Governance, 9(5), 191-201.

Comoglio, C., \& Botta, S. (2012). The use of indicators and the role of environmental management systems for environmental performances improvement: a survey on ISO 14001 certified companies in the automotive sector. Journal of Cleaner Production, 20(1), 92-102.

Cooper, A. C., Woo, C. Y., \& Dunkelberg, W. C. (1988). Entrepreneurs' perceived chances for success. Journal of Business Venturing, 3(2), 97-108.

Cortina, J. M. (1993). What is coefficient alpha? An examination of theory and applications. Journal of Applied Psychology, 78(1), 98.

Daddi, T., De Giacomo, M. R., Frey, M., \& Iraldo, F. (2017). Analysing the causes of environmental management and audit scheme (EMAS) decrease in Europe. Journal of Environmental Planning and Management, 1-20. https://doi.org/10.1080/09640568.2017.1395316

Daddi, T., Frey, M., De Giacomo, M. R., Testa, F., \& Iraldo, F. (2015). Macroeconomic and development indexes and ISO14001 certificates: a cross national analysis. Journal of Cleaner Production, 108, 1239-1248.

Daddi, T., \& Iraldo, F. (2016). The effectiveness of cluster approach to improve environmental corporate performance in an industrial district of SMEs: a case study. International Journal of Sustainable Development \& World Ecology, 23(2), 163-173.

Daddi, T., Magistrelli, M., Frey, M., \& Iraldo, F. (2011). Do environmental management systems improve environmental performance? Empirical evidence from Italian companies. Environment, Development and Sustainability, 13(5), 845-862.

Daddi, T., Tessitore, S., \& Frey, M. (2012). Eco-innovation and competitiveness in industrial clusters. International Journal of Technology Management, 58(1-2), 49-63.

Daddi, T., Testa, F., Frey, M., \& Iraldo, F. (2016). Exploring the link between institutional pressures and environmental management systems effectiveness: an empirical study. Journal of Environmental Management, 183(3), 647-656.

Daddi, T., Testa, F., Iraldo, F., \& Frey, M. (2014). Removing and simplifying administrative costs and burdens for emas and iso 14001 certified organizations: evidence from Italy. Environmental Engineering \& Management Journal, 13(3), 689-698.

Dalton, D. R., Hitt, M. A., Certo, S. T., \& Dalton, C. M. (2007). 1 The Fundamental Agency Problem and Its Mitigation: Independence, Equity, and the Market for Corporate Control. The Academy of Management Annals, 1(1), 1-64.

Delmas, M. A., \& Pekovic, S. (2013). Environmental standards and labor productivity: understanding the machanisms that sustain sustainability. Journal of Organizational Behavior, 34(2), 230-252.

Dixon, R., Mousa, G. A., \& Woodhead, A. (2005). The role of environmental initiatives in encouraging companies to engage in environmental reporting. European Management Journal, 23(6), 702-716.

Dogui, K., Boiral, O., \& Heras-Saizarbitoria, I. (2014). Audit fees and auditor independence: The case of ISO 14001 certification. International Journal of Auditing, 18(1), 14-26.

Finkelstein, S., \& Hambrick, D. C. (1996). Strategic leadership: top executives and their effects on organizations. Nashville, USA: South-Western Pub.

Fisher, C. D. (1980). On the dubious wisdom of expecting job satisfaction to correlate with performance. The Academy of Management Review, 5(4), 607-612. 
Fombrun, C., \& Shanley, M. (1990). What's in a name? Reputation building and corporate strategy. Academy of Management Journal, 33(2), 233-258.

Frondel, M., Horbach, J., \& Rennings, K. (2008). What triggers environmental management and innovation? Empirical evidence for Germany. Ecological Economics, 66(1), 153-160.

Fuller, C. M., Simmering, M. J., Atinc, G., Atinc, Y., \& Babin, B. J. (2016). Common methods variance detection in business research. Journal of Business Research, 69(8), 3192-3198.

Grolleau, G., Mzoughi, N., \& Pekovic, S. (2015). Environmental management practices: good or bad news for innovations delivering environmental benefits? The moderating effect of market characteristics. Economics of Innovation and New Technology, 24(4), 339-359.

Hackman, J. R., \& Walton, R. E. (1986). Leading groups in organizations. In P. S. Goodman (Ed.), Designing effective work groups (pp. 72-119). San Francisco: JosseyBass.

Hair, J. F., Black, W. C., Babin, B. J., Anderson, R. E., \& Tatham, R. L. (1998). Multivariate data analysis. Upper Saddle River, NJ: Prentice Hall.

Hambrick, D. C., Cho, T. S., \& Chen, M. J. (1996). The influence of top management team heterogeneity on firms' competitive moves. Admin istrative Science Quarterly, 41(4), 659-684.

Hambrick, D. C., \& Mason, P. A. (1984). Upper echelons: the organization as a reflection of its top managers. Academy of Management Review, 9(2), 193-206.

Heras-Saizarbitoria, I., Arana, G., \& Boiral, O. (2016). Outcomes of environmental management systems: The role of motivations and firms characteristics. Business Strategy and the Environment, 25(8), 545-559.

Heras-Saizarbitoria, I., Boiral, O., \& Arana, G. (2016). Renewing environmental certification in times of crisis. Journal of Cleaner Production, $115,214-223$

Heras-Saizarbitoria, I., Dogui, K., \& Boiral, O. (2013). Shedding light on ISO 14001 certification audits. Journal of Cleaner Production, 51, 88-98.

lacobucci, D. (2010). Structural equations modeling: Fit Indices, sample size, and advanced topics. Journal of Consumer Psychology, 20(1), 90-98.

laffaldano, M. T., \& Muchinsky, P. M. (1985). Job satisfaction and job performance: a meta-analysis. Psychological Bulletin, 97(2), 251-273.

Jensen, M. C., \& Meckling, W. H. (1976). Theory of the firm: Managerial behavior, agency costs and ownership structure. Journal of Financial Economics, 3(4), 305-360.

Judge, T. A., Thoresen, C. J., Bono, J. E., \& Patton, G. K. (2001). The job satisfaction-job performance relationship: a qualitative and quantitative review. Psychological Bulletin, 127(3), 376-407.

Lanoie, P., Laurent-Lucchetti, J., Johnstone, N., \& Ambec, S. (2011). Environmental Policy, Innovation and Performance: New Insights on the Porter Hypothesis. Journal of Economics \& Management Strategy, 20(3), 803-842.

Lim, S., \& Prakash, A. (2014). Voluntary regulations and innovation: the case of ISO 14001. Public Administration Review, 74(2), 233-244.

Melnyk, S. A., Sroufe, R. P., \& Calantone, R. (2003). Assessing the impact of environmental management systems on corporate and environmental performance. Journal of Operations Management, 21(3), 329-351.

Merli, R., \& Preziosi, M. (2018). The EMAS impasse: Factors influencing Italian organizations to withdraw or renew the registration. Journal of Cleaner Production, 172, 4532-4543.

Merli, R., Preziosi, M., \& Ippolito, C. (2016). Promoting sustainability through EMS application: a survey examining the critical factors about EMAS registration on Italian organizations. Sustainability, 8(3), 1-14.

Miles, J. A. (2012). Management and organization theory: a Jossey-Bass reader (Vol. 9). Hoboken, USA: John Wiley and Sons.

Morrow, D., \& Rondinelli, D. (2002). Adopting corporate environmental management systems: Motivations and results of ISO 14001 and EMAS certification. European Management Journal, 20(2), 159-171.
Netemeyer, R. G., Maxham, J. G., \& Lichtenstein, D. R. (2010). Store manager performance and satisfaction: effects on store employee performance and satisfaction, store customer satisfaction, and store customer spending growth. Journal of Applied Psychology, 95(3), 530.

Nishitani, K., Kanekob, S., Fujiic, H., \& Komatsu, S. (2012). Are firms' voluntary environmental management activities beneficial for the environment and business? An empirical study focusing on Japanese manufacturing firms. Journal of Environmental Management, 105, 121-130.

Osterloh, M., Frost, J., \& Frey, B. S. (2002). The dynamics of motivation in new organizational forms. International Journal of the Economics of Business, 9, 61-77.

Podsakoff, P. M., MacKenzie, S. B., Lee, J. Y., \& Podsakoff, N. P. (2003). Common method biases in behavioral research: A critical review of the literature and recommended remedies. Journal of Applied Psychology, 88, 879-903.

Porter, M., \& van der Linde, C. (1995). Toward a new conception of the environment competitiveness relationship. Journal of Economic Perspectives, 9(4), 97-118.

Potoski, M., \& Prakash, A. (2013). Do voluntary programs reduce pollution? Examining ISO 14001's effectiveness across countries. Policy Studies Journal, 41(2), 273-294.

Rennings, K., Ziegler, A., Ankele, K., \& Hoffmann, E. (2006). The influence of different characteristics of the EU environmental management and auditing scheme on technical environmental innovations and economic performance. Ecological Economics, 57(1), 45-59.

Schwab, D. P., \& Cummings, L. L. (1970). Theories of performance and satisfaction: a review. Industrial Relations A Journal of Economy and Society, 9(4), 408-430.

Spence, A. M. (1974). Market signaling: Informational transfer in hiring and related screening processes (Vol. 143). Cambridge, MA: Harvard University Press.

Strauss, G. (1968). Human relations - 1968 Style. Industrial Relations, VII(May 1968), 264.

Tessitore, S., Daddi, T., \& Iraldo, F. (2013). The link between environmental and economic performance: evidence from some eco-innovative industrial clusters. International Journal of Environment and Sustainable Development, 12(2), 125-144.

Testa, F., Boiral, O., \& Iraldo, F. (2018). Internalization of environmental practices and institutional complexity: Can stakeholders pressures encourage greenwashing? Journal of Business Ethics, 147(2), 287-307.

Testa, F., Heras-Saizarbitoria, I., Daddi, T., Boiral, O., \& Iraldo, F. (2016). Public regulatory relief and the adoption of environmental management systems: a European survey. Journal of Environmental Planning and Management, 59(12), 2231-2250.

Testa, F., Iraldo, F., \& Daddi, T. (2018). The effectiveness of EMAS as a management tool: a key-role for the internalization of environmental practices. Organization \& Environment, 31(1), 48-69.

Testa, F., Rizzi, F., Daddi, T., Gusmerotti, N. M., Frey, M., \& Iraldo, F. (2014). EMAS and ISO 14001: the differences in effectively improving environmental performance. Journal of Cleaner Production, 68, 165-173.

Triguero, A., Moreno-Mondéjar, L., \& Davia, M. A. (2013). Drivers of different types of eco-innovation in European SMEs. Ecological Economics, 92, 25-33.

Vroom, V. H. (1964). Work and motivation. New York: Wiley.

Wätzold, F., Bültmann, A., Eames, M., Lulofs, K., \& Schucht, S. (2001). EMAS and regulatory relief in Europe: lessons from national experience. Environmental Policy and Governance, 11(1), 37-48.

Weiss, D., Skinner, A., Smyth, M., Kahlenborn, W., Iraldo, F., Daddi, T., ... Melis, M. (2015). Final Report - Supporting the Evaluation of the Implementation of EMAS (Vol. 2015). Brussels: European Commission.

Wiersema, M. F., \& Bantel, K. A. (1992). Top management team demography and corporate strategic change. Academy of Management Journal, 35(1), 91-121. 
Yee, R. W. Y., Yeung, A. C. L., \& Edwin Cheng, T. C. (2008). The impact of employee satisfaction on quality and profitability in high-contact service industries. Journal of Operations Management, 26, 651-668.

Zahra, S. A., \& Das, S. R. (1993). Innovation strategy and financial performance in manufacturing companies: An empirical study. Production and Operations Management, 2(1), 15-37.

Ziegler, R., Hagen, B., \& Diehl, M. (2012). Relationship between job satisfaction and job performance: job ambivalence as a moderator. Journal of Applied Social Psychology, 42(8), 2019-2040.

Zobel, T. (2016). The impact of ISO 14001 on corporate environmental performance: a study of Swedish manufacturing firms. Journal of Environmental Planning and Management, 59(4), 587-606.
Zorpas, A. (2010). Environmental management systems as sustainable tools in the way of life for the SMEs and VSMEs. Bioresource Technology, 101(6), 1544-1557.

How to cite this article: Daddi T, Iraldo F, Testa F, De Giacomo MR. The influence of managerial satisfaction on corporate environmental performance and reputation. Bus Strat Env. 2019;28:15-24. https://doi.org/10.1002/bse.2177 